NBER WORKING PAPER SERIES

\title{
WHY DO SO MANY YOUNG AMERICAN MEN COMMIT CRIMES AND WHAT MIGHT WE DO ABOUT IT?
}

Richard B. Freeman

Working Paper 5451

\section{NATIONAL BUREAU OF ECONOMIC RESEARCH \\ 1050 Massachusetts Avenue \\ Cambridge, MA 02138 \\ February 1996}

This paper was written while a visitor at the Centre for Economic Performance, London School of Economics, London, Great Britain. The research for this paper was funded in part by the Rockefeller Foundation. This paper is part of NBER's research program in Labor Studies. Any opinions expressed are those of the author and not those of the National Bureau of Economic Research.

(C) 1996 by Richard B. Freeman. All rights reserved. Short sections of text, not to exceed two paragraphs, may be quoted without explicit permission provided that full credit, including $(\mathcal{C}$ notice, is given to the source. 
NBER Working Paper 5451

February 1996

\title{
WHY DO SO MANY YOUNG AMERICAN \\ MEN COMMIT CRIMES AND WHAT \\ MIGHT WE DO ABOUT IT?
}

\begin{abstract}
This paper shows that participation in crime and involvement with the criminal justice system has reached extraordinary levels among young men. With approximately 2 percent as many men incarcerated as in the labor force, the crime rate should have plummeted. It didn't. Evidence suggests that the depressed labor market for low skill American workers contributed to the continued high level of crime by less educated men, despite incapacitation and the deterrent effect of imprisonment. The costs of incarceration are such that even marginally effective prevention policies can be socially desirable.
\end{abstract}

Richard B. Freeman Department of Economics Harvard University Cambridge, MA 02138 and NBER 
In the past two decades or so, more and more American men, particularly the young, the less educated, and blacks, have been involved in crime, despite an increased risk of imprisonment. From the mid-1970s to the mid-1990s, the United States roughly tripled the number of men in prison or jail, so that by 1993 one man was incarcerated for every fifty men in the work force. Incapacitation of so many criminals should have greatly reduced the crime rate: if the worst offenders are in prison, they can't mug, rob, or otherwise commit offenses against the citizenry. But no such drastic reduction in crime occurred. The number of crimes reported to the police roughly stabilized while the rate of victimizations (which includes crimes not reported to the police) dropped far less rapidly than could reasonably be expected. Noninstitutionalized men evidently "replaced" incarcerated criminals in committing crimes.

Why? What induces young American men, particularly less educated and black men, to engage in crime in large numbers despite the risk of imprisonment? Is the rising rate of criminal involvement related to the collapse in the job market for the less skilled? Is "locking them up" the only efficacious way to fight crime?

In this essay I examine these questions. I show that participation in crime and involvement with the criminal justice system has reached such levels as to become part of normal economic life for many young men. I present evidence that labor market incentives influence the level of crime and argue that the depressed labor market for less skilled men in the 1980s and 1990s has contributed to the rise in criminal activity by less skilled men. Given the high costs of crime and imprisonment, even marginally effective crime prevention policies can be socially desirable. 


\section{Magnitudes of Criminal Involvement}

The participation of American men in crime is staggering. Consider first the number of men convicted of crime and sent to prison or jail. In 1993910,000 were in state or federal prison; an additional 440,500 were in jail, for a total of $1,350,500$ incarcerated. $^{1}$ With a male workforce of 69.6 million or so, this is one man incarcerated for every fifty men in the workforce! This proportion is approximately the same as the share of long-term unemployed men on the dole in many western European countries. For every person incarcerated in the United States, approximately 2.1 were on probation and 0.5 were on parole -- an additional 3,511,300 men with criminal involvement. All told, 7 percent as many men were "under the supervision of the criminal justice system" (incarcerated, paroled, or probated) as were in the work force. ${ }^{2}$

Most of those involved in crime are young. In 1993, 2.9 percent of 25-34 year old American men were incarcerated. ${ }^{3}$ Approximately 10 percent of men in this age group were under supervision of the criminal justice system.

Many of those involved in crime are black. In 1993, about 7 percent of black men over 18 were incarcerated. There was one black man was in prison for every eleven black men in the workforce; and approximately one under supervision of the criminal justice system for every three to four black men in the workforce. Combine race and age, and you find that 12 percent of black men aged 25-34 were incarcerated.

A disproportionate number of men in prisons are high school dropouts: the 1991 Survey of State Prison Inmates reports that two-thirds had not graduated high school, though many had obtained a general equivalency degree (U.S. Department of Justice, Bureau of Justice 
Statistics, 1993). Among 25-34 year olds, approximately 12 of male dropouts were incarcerated in 1993.

Combine race, age, and education: in 1993, 34 percent of high school dropout 25-34 year old black men were incarcerated. Since many of those non-institutionalized will be put on probation or released on parole, a majority of the young male black dropout population -which make up 15 percent of black men aged 25-34 -- is under supervision of the criminal justice system. ${ }^{4}$

When prisoners complete their sentences, a large number do not return to society rehabilated to enter the job market. Prisoners have high recidivism rates (Needels, 1993). Many offenders sentenced to prison eventually return to society with their labor market skills and opportunities reduced and their criminal skills and opportunities enhanced. Young men who have been incarcerated have poor employment records years into the future, controlling for many observable factors and in comparison to their own pre-prison employment record (Freeman, 1992). Criminality declines with age (raising questions the extent to which incarceration of aged criminals reduces crime), but crime is not a "teenage thing." Rather, the population of offenders are a relatively permanent part of American society -- an "underclass" problem group that will not disappear naturally.

The numbers incarcerated or under supervision of the criminal justice system in the United States are a decimal place beyond comparable statistics in other advanced countries. In the United Kingdom, which has the highest rate of incarceration in western Europe, approximately 50,000 men were in prison in $1993,0.3$ percent of the number in the work force. The 1992 incarceration rate for the entire population in the U.S. was five to ten times 
that for western European countries (Central Statistical Office, p. 167).

What is comparable in western Europe to the U.S. prison population are men who have been unemployed and on the dole for a long time. In 1992, approximately 2.0 percent of the male workforce was unemployed for over one year in Europe's largest economy, Germany. In the United Kingdom, the figure was 5.1 percent. In France, it was 2.6 percent. $^{5}$ Europe's long-term jobless are also removed from the normal job market on a relatively permanent basis. Many leave unemployment to obtain disability insurance or early retirement, rather than to return to the normal job market.

The numbers incarcerated or under supervision do not measure the current rate of criminal participation. Not every criminal is caught and arrested, much less locked up. Persons under probation or parole may commit some crimes, but those not yet under supervision of the criminal justice system commit many as well.

One way to determine participation in crime is through household surveys, which ask respondents whether or not they committed crimes over some time period. A surprisingly large number of young men self-report criminal involvement, especially in samples that cover poor inner city neighborhoods or that oversample the disadvantaged. In one widely used survey, the National Longitudinal Survey of Youth (which oversamples youths from poorer family backgrounds) 41 percent of young men admitted in 1980 that they had committed crimes in the previous year. In the 1989 Boston Youth Survey, 23 percent said that they had committed crimes (Freeman, 1993, table 6.3). Studies that seek to verify self-reported criminal behavior (say, by checking police records on arrests) find that white youths give reasonably accurate reports, but that black youths understate their criminal involvement 
(Hindelang, Hirschi, and Weiss, 1981).

Another way to estimate the number of persons in the non-institutional population involved in crime is to divide numbers of crimes by crimes committed per criminal (called lambda by criminologists). Because estimates of the number of crimes per criminal differ greatly, there is a wide band of uncertainty around this calculation. Studies of prisoners suggest an average number of crimes of approximately 60 to 180 per year (Marvell and Moody, 1994, table 1), though one may be suspicious of self-reported numbers on the order of 180. But because a small number of criminals report committing a large number of crimes, the median number of offenses per prisoner is just 12-15 per year. Since prisoners are a high offending group, moreover, their crime rates should exceed those of the nonincarcerated population. Criminologists also estimate crimes per criminal by asking persons arrested how many times they were arrested; and dividing the number of arrests by police data on the arrests per crime. These estimates suggest a rate around 11 (Marvell and Moody, 1994, p. 112). Finally, we have numbers of crimes reported by youths on household surveys. In the NLSY, non-incarcerated youths who admit having committed crimes report 7 crimes over the year.

Given 15 million crimes reported to the police, $60-180$ crimes per criminal implies that there are just 83,000 to 250,000 criminals; 12 crimes per criminal implies one million persons in the noninstitutional population committing crimes in a year; 7 crimes per criminal implies 2.1 million persons committing crimes. Since 2.3 million arrests are made for "serious crimes" each year and some 8.5 million arrests are made for "nonserious crimes", I regard as reasonable the estimate that about 2 million noninstitutionalized persons commit 
crimes each year. The bottom line is clear: crime is a substantial activity among men in the United States. Given the age, race, and education background of those incarcerated or arrested, it is a major activity among important subgroups.

\section{Trends in Criminal Participation}

As noted at the outset, mass incarceration of criminals should have reduced crime substantially. That it did not implies that there was a major increase in criminal activity among the noninstitutionalized population. How big was this increase? For the period from 1977 to 1992 , I estimated the trend in criminal activity by the noninstitutional population through a three step procedure.

First, I calculated the reduction in crime due to the increased incapacitation of criminals under conservative assumptions about the number of crimes the newly incarcerated would have committed had they been on the street. As a simple example, assume a population of 100 , in which there are 40 crimes committed a year, so that the crime/person ratio is .40 . If each criminal commits ten crimes, there are four criminals in the population. When the government apprehends and imprisons two criminals, the crime/person ratio should, by the incapacitation effect, fall roughly in half, to .204 (20/98).

Second, I compared this expected number of crimes to the actual number of crimes as reported by the Uniform Crime Report of the FBI or National Crime Survey on victimization. ${ }^{6}$ In the illustration given a moment ago, any crime rate beyond .204 implies that those not previously committing crimes are now doing so or that those committing crimes now commit more. 
Third, I divided crimes committed to the predicted number to obtain an index of the "Propensity to Commit Crime." This propensity reflects both the rate of participation of noninstitutionalized men in crime and the intensity of criminal activity. In the illustrative example, if 30 crimes were committed instead of the predicted 20 , then the propensity would have risen 50 percent; if $\mathbf{4 0}$ crimes were committed, the propensity would have risen 100 percent. If the number of crimes committed per criminal remains constant, then changes in the calculated propensity must reflect a greater amount of criminal participation.

Exhibit 1 shows the trends resulting from these calculations, with the propensity to commit crime in 1977 being normalized at 100 . Using 1977 as a base year is designed to choose a year not too far in the past, but prior to the large increase in the jail and prison population. One line in Exhibit 1 shows the results of basing this calculation on 10 crimes committed per person incarcerated, a figure based on the Uniform Crime Report statistics. The calculations indicate that if the propensity to commit crime had not increased, then the increase in the prison/jail population should have more than halved the number of crimes committed per male. But between 1977 and 1992, the crimes committed per male rose modestly. Thus, the propensity for criminal activity by non-institutionalized men increased by 163 percent.

The second line on Exhibit 1 reports similar calculations using the victimization data. In this calculation, based on the National Crime Survey, I assume the number of victimizations per criminal to be 30 . The result is an estimate that criminal propensity increased by 80 percent from 1977 to 1992 . Alternative estimates of crimes per incarcerated person give different magnitudes to the rise in propensity without altering the message: the rate of 
criminal activity among non-institutionalized men rose sharply in this period.

\section{Labor Market Causes of Crime}

The correlates and causes of crime are complex and varied: among the factors considered by criminologists are age, sex, family background, intelligence, bio-medical factors, community conditions, race, crime control strategies, and economic factors (Wilson and Petersilia, 1995). Without downplaying this complexity, I want to direct attention to the proposition, dear to the heart of economists, that labor market incentives influence the supply of men to crime, and, in particular, that collapse of the job market for less skilled men during the 1980s and 1990s may have contributed to their increased rate of criminal activity.

For the change in the labor market to help explain the high and rising rate of criminal participation among American men, it is necessary that: a) the economic rewards from crime rose relative to those from legal work; and b) young men respond significantly to relative rewards.

\section{The Relative Rewards of Crime}

The pecuniary return to crime depend on legitimate earnings opportunities, criminal earnings opportunities, the likelihood that crime will succeed, and the penalty that a criminal will pay if caught.

It is well-established that the legitimate earnings opportunities of low skill men deteriorated substantially from the mid-1970s through the 1990s. Real earnings fell sharply for the least educated and for those in the bottom rungs of the earnings distribution. The 
exact magnitude of the decline in earnings depends on the specific measure of earnings chosen, the deflator, years picked, the age and skill group chosen, and so on, but drops on the order of 20-30 percent that accelerated in the 1990s are a reasonable estimate (Mishel and Bernstein, 1994). Despite the putative job-creating effects of reduced pay, there was no offsetting improvement in hours worked or employment/population rates for the less skilled. To the contrary, hours worked over the year fell among those in the bottom rungs of the wage distribution (Juhn, Murphy, and Topel, 1991); and employment-population rates for this group worsened in the 1970s, though not in the 1980s (Blackburn, Bloom, and Freeman, 1990). The implication is that demand for less skilled male labor plummetted.

On the other side of the incentive equation are criminal earnings. Because criminals are not forthcoming about their incomes, we do not have good estimates of how much crime pays, much less of how criminal earnings have changed over time. ${ }^{7}$ However, responses to survey questions on perceived criminal opportunities suggest that criminal rewards have increased, at least among youth. In 1980, the NBER Inner City Youth Survey asked youths in Boston, Chicago, and Philadelphia whether they thought they could make more "on the street" than in a legitimate job. It also asked them about their perceptions of the availability of criminal opportunities. The 1989 Boston Youth Survey, conducted at the peak of the booming "Massachusetts Miracle" job market, asked the same questions. Between these dates, the proportion of youths who reported that they could earn more on the street went up, from 31 percent in the three cities and 41 percent in Boston in 1980 to 63 percent in Boston in 1989. Similarly, the proportion who said they had "chances to make illegal income several times a day" roughly doubled over the period, to reach nearly 50 percent in 1989 
(Freeman, 1992).

Youths who made money from crime in the 1980 NBER Survey of Inner City reported average annual criminal earnings of $\$ 1,807$ per year, whereas in the 1989 Boston Youth Survey annual youths reported average criminal earnings of $\$ 3,008$-- which, deflated, implies a real increase of some 5 percent. $^{8}$ Annual criminal earnings are, the reader will note, not large. Even young men who said they committed crimes weekly in 1989 reported earning just $\$ 5400$ over the year. But transformed into "hourly rates, "these figures imply hourly earnings from crime of around $\$ 10.00$ for criminal activity in Boston in 1989 . This exceeds the $\$ 7.50$ youths reported from legitimate work and the $\$ 5.00$ or $\$ 6.00$ or so they would take-home pay from that work after Social Security and tax deductions. ${ }^{9}$

Estimates of the earnings for adult criminals tell a similar story. Reuter, MacCoun, and Murphy (1990) surveyed drug dealers in Washington, D.C., and found that they earned $\$ 2000$ per month net of expenses, which translated into $\$ 30$ per hour, making drug selling "much more profitable on an hourly basis than are legitimate jobs available to the same person" (Reuter et al., 1990, p. viii). They further estimated that the illegitimate earnings of drug dealers exceeded their legitimate earnings by enough to make it financially worth their while to spend one year in jail for every two years they sold drugs. Using the 1986 Survey of Prison Inmates, I found that criminals who said all of their earnings came from crime made $\$ 24,775$ per year (Freeman, 1993), a figure comparable to Reuter's $\$ 2000$ a month, but so few criminals reported that all their earnings were from crime to make this an unrepresentative statistic. On the other hand, Wilson and Abrahamse (1991) stress that criminal earnings from burglary/theft, robbery, and swindling are not that high and and may 
fall short of the legitimate earnings available to those criminals (though not necessarily on an hourly basis).

A potentially important factor contributing to criminal earnings and crime is the demand for drugs, which may have increased in the period due in part to the development of new products and sources of drugs. A huge proportion of persons arrested for nondrug crimes -from 50 to 80 percent -- tested positive for drugs in 1992 (U.S. Bureau of the Census, 1993, table 315). A substantial proportion of prisoners have been incarcerated for drug offenses. Some persons commit crimes to make money to buy drugs: Boyum and Kleiman (1995) note that 39 percent of cocaine and crack users claim to have committed crime to get money to buy drugs. Others commit the crime of trying to meet the market demand. While we lack any valid time series measure of the shift in demand for drugs, most analysts believe that this has raised criminal earnings opportunities.

The pecuniary returns to crime depend on an additional factor: the probability that the individual succeeds with the crime. If a youth is caught, he is likely to gain little from the crime. If he is incarcerated, he obtains no legitimate earnings during his sentence, and likely as not, will have fewer legitimate earnings opportunities upon release. Since the probability of incarceration increased in the 1980s, it is possible that the relative rewards to crime actually fell, despite the sharp drop in legitimate earnings. To assess this possibility, I have examined Langan's (1994, table 4) estimates of the increase in the chance of imprisonment for various crimes from 1974 to 1986 . The largest increase is 9.1 percentage points for robbery. Langan (table 1) finds that the median time served before release in prison in 1986 was 15 months. Thus, the increase in incarceration would cut a criminal's legitimate earnings 
by 11 percent $(1.25 \times .091)$ if he were fully employed during the period. This falls far short of the 30 percent drop in real earnings from legitimate work.

A more detailed analysis would contrast the effects of the fall in legal earnings and of the increased risk of incarceration on lifetime incomes. This might involve various long term factors: how imprisonment raises the likelihood of more severe sentences in the future; the reduction in future legal employment opportunities; a possible increase in future illegal opportunities (!); and so on. But given the magnitude of decline in legitimate earnings, and probable increase in criminal earnings, I doubt that the increased chance of incarceration would tip the balance of the income calculation toward steering young men away from criminal activity.

If incarceration carries with it substantial non-pecuniary costs (prisons are not pleasant places unless you are a high earner white collar criminal), the increased chance of incarceration might still have deterred crime. But as more and more young men from low income neighborhoods are incarcerated, many observers believe that one traditional nonpecuniary cost of imprisonment -- the stigma attached to having a criminal record by friends and neighbors - has weakened greatly. Some criminologists, in fact, speculate that the stigma of incarceration falls with the proportion incarcerated, weakening the effect of prison as a deterrent to crime.

My bottom-line assessment of the pecuniary side of the calculus is that earnings from crime increased relative to earnings from legal work in the 1980s, and that the hourly rewards to crime exceeded the hourly rewards from legal work. The next question is whether the magnitude of supply response to the change in returns is large enough to have 
contributed significantly to the rise in criminal propensity.

\section{Responses to the Return to Crime}

There is diverse evidence that young men respond to economic incentives for crime and that their response may be sufficiently large to play a role in the rise in criminal propensity.

First, the demographics of the criminal population show that those who commit crimes consist disproportionately of persons with low legitimate earnings prospects -- the young, the less educated, persons with low test scores, and so on. It is at least plausible that these characteristics are a greater limitation on earning in legal activities than in illegal activities. In fact, some evidence from the NLSY suggests that schooling, age, and test scores pay off more in the normal job market than in crime. ${ }^{10}$

Second, joblessness seems associated with greater crime (Chiricos, 1987; Freeman, 1983, 1994). For example, areas with high unemployment tend to have high crime rates, though coefficients of response are not large. Time series studies also generally find that unemployment or related measures of aggregate labor market activity are associated with rises in crime, though this cyclical relation has little to do with secular changes in crime. Comparisons of individuals show that those who commit crimes are more likely to do so when they are unemployed. Longitudinal evidence shows, moreover, that persons engaged in "serious violent behavior" are more likely to terminate this if they are employed than if they are unemployed (Elliot, 1994, table 1).

Third, greater inequality is associated with higher rates of crime (Chiricos, 1987; Freeman, 1983, 1994). Even homicide rates are correlated with measures of inequality 
across cities (Land, McCall, and Cohen, 1990) . In the most comprehensive study, Lee (1993) found a substantive positive relation between levels of earnings inequality and crime rates across metropolitan areas in 1970 and 1980. His estimates suggest that the increased inequality in the 1980s induced a 10 percent increase in crime, as measured by the FBI's Uniform Crime Report index. However, when Lee compared changes in inequality with changes in crime among metropolitan areas, he found no relation. Perhaps this is because measures of changes in inequality reflect noise in the data, but perhaps it is a clue that the cross-area relation reflects an omitted area variable rather than a true link from inequality to crime.

Fourth, individuals who commit crime have lower perceptions of the riskiness of crime, higher assessments of the relative earnings of criminal behavior, and lower legitimate hourly pay. Using the NBER Inner City Youth Survey, Viscusi (1986) found that perceptions of risk and earnings opportunities influenced the supply of young blacks to crime. Using the same survey, I found a significant positive relation between criminal participation and whether individuals thought they could earn more on the street than in the job market (Freeman, 1987). Using the NLSY, Grogger (1994) estimated a supply elasticity to crime with respect to wages near unity for young men which, applied to the observed drop in real earnings of less skilled young men, predicted a 23 percent increase in crimes committed by these youths from the mid-1970s to the late 1980s, which he points out is of comparable magnitude to the 18 percent increase in the index arrest rate for young men over the period.

Exhibit 2 shows that one does not need complicated calculations to find a relation between the relative rewards to crime and future criminal behavior. In 1980, the NLSY 
asked respondents the proportion of their income that came from illegal activity. Those who had a high proportion of income from crime, presumably had relatively high criminal pay compared to legitimate pay (controlling for time worked at legitimate jobs, and the number of crimes committed) and thus should thus be more involved in crime than others, and more likely to end up incarcerated in the future. ${ }^{11}$ As the exhibit shows, the proportion of income from illegal sources in 1980 does in fact help explain incarceration years into the future (more refined calculations correcting for time worked at legitimate jobs, crimes committed, and so on, confirm this finding).

Fifth, time worked by men in the lower deciles of the earnings distribution fell in the 1980s as their real earnings fell (Topel, 1993; Juhn, Murphy, and Topel, 1991; Freeman, 1995), with a magnitude that suggests a non-negligible supply elasticity. Juhn, Murphy, and Topel (table 9) estimate that the elasticity of labor supply with respect to wages of young men in the lower deciles of the earnings distribution is on the order of 0.20 to 0.30 . The finding that low paid men worked less as their real wages fell is consistent with an increased allocation of time to crime, though it does not imply that they did in fact allocate their increased non-work time to crime.

Sixth, many youths combine crime and work or shift between them readily. Because most criminals are self-employed, and because the U.S. job market has considerable flux, crime and legitimate work are not dichotomous choices for most young men. Joe holds a job; robs someone he meets on a dark empty street; sells drugs on the weekend. Harry sells drugs for a while, decides the street is too dangerous, gets a legitimate job for a while, loses that job and goes back to selling drugs. Ethnographic research shows that legal and illegal 
work often overlap among young drug sellers: for example, Fagan (1991) and Reuter, MacCoun, and Murphy (1990) point out the phenemonon of "doubling up" of legal work and cocaine sales. This and other evidence (Hageborn, 1994) indicates that for many young men, illegal work may be temporary or transitional work that supplements difficult low wage or otherwise unsatisfactory work. For others, legal work provides options to riskier illegal work, or perhaps broadens markets for sellers of illegal goods or services.

Exhibit 3 records the employment status of young men in the NLSY according to four measures of criminal activity: committing a crime; earning illegal income; being charged with a crime; and being incarcerated in the following year. The sample is limited to out-ofschool youths not involved in military service. The crimes are limited to a subset of economic crimes, including shoplifting, stealing, using force to obtain things, selling drugs, conning someone, stealing an automobile, breaking into a building, or aiding a gambling operation. ${ }^{12}$ The data show that those involved in crime have lower rates of employment than those not involved in crime. But the magnitude of the employment gap is modest for those with low level of criminal involvement: a 3 point difference between those who committed and those who did not commit crime; a 7 point difference between those with positive incomes from crime and those without such income; a 13 point difference between those charged with crime and those not charged. Only among youths who end up incarcerated a year later are crime and work roughly mutually exclusive: here the difference in employment rates is 35 points.

The ethnographic reports and NLSY data show that for many youths the line between legal and illegal work is not a sharp one: both are ways to make money. This pattern could 
readily make the supply of youths to crime highly elastic. Assume that young men have reservation wages for legitimate work and for criminal work. Opportunities for both types of earnings activities arise intermittently, and youths act on them when the expected rewards exceed their reservation wages. In the NBER Inner City and Boston Youth surveys, many young men in inner city poverty areas reported frequent illegal and legal earnings opportunities. Someone may need help selling stolen goods; a car with a stereo may be parked on a deserted street; the local fast food franchise or supermarket may be hiring. If the opportunity is there, and if the likely gain exceeds the reservation wage, someone will act on it.

In sum, while we do not have a well-determined elasticity of the supply of youths to crime (any more than we have well-determined elasticities of demand or supply of many consumer goods), a collage of evidence supports the notion that young men respond substantially to the economic returns to crime. If the supply is reasonably elastic, moreover, it is easy to see why the standard incapacitation model -- lock them up, they can't commit crime, so crime falls -- failed to fit U.S. experience in the 1980s and 1990s. An infinitely elastic supply of crime implies a zero incapacitation effect, since each criminal locked up is replaced by another. ${ }^{13}$ The incapacitation model may also fail to work well because legal earnings fell (as has happened since the 1970s) and or criminal opportunities increased (perhaps because of a growth in the market for illegal drugs) and offset incapacitation effects. By focusing on the individual rather than the market, standard incapacitation models overstate the effect of increased imprisonment on crime. But even a zero incapacitation effect does not mean that society fails to gain from locking up criminals: there may still a 
substantial deterrence effect from incarceration that would reduce the supply curve of young men to crime.

To identify the "true" effects of higher rates of imprisonment on crime, it is necessary to examine the relation between crime and changes in the prison population. Using a comparison across states, Marvell and Moody (1994) estimate that a 10 percent increase in the prison population reduces crime by 1.6 percent; Spelman (1994) gives comparable estimates. Levitt (1995) uses state litigation suits about prison conditions as an instrumental variable -- more suits exogenously reduce the prison population -- and finds that a 10 percent increase in the prison population reduces crime by 4 to 6 percent. These estimates of the reduction in crime due to increased imprisonment include labor supply responses (deterrence of crime due to greater risk; replacement of criminals due to greater opportunities), in addition to the traditional incapacitation effect. ${ }^{14}$

\section{Crime, Incarceration, and Economic Life}

There are two indicators of the aggregate cost of crime to society. At one extreme, imagine a society that spent nothing on crime control. The aggregate cost of crime to legitimate society would then be the loss of property, lives, and misery due to crime. ${ }^{15}$ At the other extreme, imagine a society that spends so much for crime control that no crimes are committed. The cost of crime would then be the opportunity cost of crime control resources -- prison, police, private spending -- that could be spent on other activities. As an example of this second cost of crime to society, consider this description in the New York Times (April 12, 1995, p. A21) of the fiscal situation in California: "In 1995 California 
spent more on prisons than on the higher education. Spending on prisons rose from 2 percent of the state budget in 1980 to 9.9 percent in 1995 whereas spending on higher education shrunk from 12.6 percent in 1980 to 9.5 percent. The number of inmates increased from 23,500 to 126,100 over the period and 17 new prisons were built. This was before the state's 'three strikes and you're out' law."

All societies are somewhere between these two extremes. The potential losses from crime lead to some spending on crime control. The costs of crime control lead to some "acceptable" level of crime. At the social optimum, society would spend just enough on crime control so that the marginal dollar spent (adjusted for deadweight loss of raising the dollar) equals the marginal reduction in social costs of crime. This requires knowledge of how social costs vary with the number of crimes, and of the effectiveness of different crime control programs.

Estimates of the average cost of crime, much less of the marginal cost, are difficult to make. The National Crime Survey estimates the direct monetary losses of crimes by asking victims to estimate losses from theft or damage, medical expenses, and any pay losses due to injury. The 1992 estimate was that the average burglary cost $\$ 834$, the average auto theft, $\$ 3990$, the average robbery $\$ 555$, and so on (Klaus, 1994). The average crime was estimated to cost victims 3.4 days of working time. The total economic loss to victims of crime, including medical costs and lost worktime, was estimated to be $\$ 532$ per crime or $\$ 17.6$ billion for all reported crimes in that year. This is 0.3 percent of GDP.

Some criminologists have expanded these estimates to find a more inclusive cost of crime, based on jury evaluation of non-pecuniary costs (Cohen, 1988); and offer a more 
extensive medical evaluations of injuries, including psychological problems (Miller, Cohen, and Rossman, 1993). These estimates are rough ones. Jury cases may involve greater misery than other victimizations. Some estimates include the lost legitimate earnings of incarcerated criminals, which may affect the well-being of spouses or children -- 56 percent of male prisoners have children under the age of 18 (Bureau of Justice Statistics, 1991, p. 10), and which may lead to social transfers to their families. Others exclude lost earnings of the criminal, on the argument that the criminal consumes most of those earnings (Levitt, 1995). None include the suffering of the families of criminals. For all their problems, these estimates are undoubtedly closer to the truth than figures limited to the money stolen, and they exceed reported monetary losses by massive amounts. For example, the estimated average pain and suffering and cost of risk of death created by a robbery is approximately eleven times the direct monetary loss (Cohen, 1988, table 3). Estimates of the cost of pain, suffering, and economic loss for the average crime are on the order of $\$ 2,300$ (Dilullio and Piehl) to $\$ 3,000$ (Levitt, 1995). ${ }^{16}$ With 14.1 million crimes committed in 1993, according to the Uniform Crime Report, this cumulates to $\$ 32-42$ billion, or 0.5 to 0.7 percent of GDP.

Of course, the crimes actually reported to police and recorded in the Uniform crime report are far less than the number of victimizations. It's not clear whether the average victimization would cause a loss higher or lower than the average crime. Some victimizations -- such as the robbery of bicycles -- cost less; others like rape, child abuse, or domestic violence not reported to police may cost more. If the cost of an average crime is kept at the same rate, but multiplied by the number of victimizations reported, the social cost reaches 


\section{2 to 1.6 percent of GDP.}

Finally, there is the additional loss of production by the incarcerated (which accrues largely to them). Prisoners are low skill, and many would be jobless if they were free, but not committing crimes. Still, 2 percent of even low skill male workers would add perhaps 0.5 to 0.7 percent to GDP, giving a total cost of around 2 percent of GDP due to crime. These costs underlie the case for allocating considerable resources to crime control activities, including prison or alternative sentencing, and for any social programs that can prevent crime.

The resources that the state and individuals spend to control crime are more directly measurable. Most resources to control crime are public. Total expenditures on the criminal justice system in 1990 was $\$ 74$ billion, or 1.3 percent of GDP. Total employment in the system was around 2 percent of U.S. employment. Within the criminal justice system, corrections (which includes prisons) are a major cost item. In $1990, \$ 25$ billion were spent on corrections. With 1.14 million persons in prison or jail in that year, the average cost is $\$ 22,000$ per person. ${ }^{17}$ Of course, the public cost must also be multiplied by the deadweight loss created by distortions of taxation or deficit financing.

Another big ticket item is private crime prevention resources. Private security guards are one of the fastest growing occupations in the United States, accounting for 0.6 percent of employment in 1992. Both households and offices undertake many crime prevention measures. Individuals allot additional resources through such diverse decisions as taking a taxi instead of walking home from the movies; locating a business in the suburbs instead of a central city, and so on. My guestimate is that on the order of 0.6 percent of GDP is spent 
on private crime prevention, ranging from guards to various protective devices.

All told, approximately 2 percent of GDP is allotted to crime control activities. From one perspective, this is simply part of the overhead of running a modern society and trying to enforce rules of conduct and protect citizens. From another perspective, it is pure waste. Measured in terms of spending, if we could make contracts with potential criminals to forego crime or devise policies to train them or to subsidize their employment so that they would forego crime, one might think that we could spend up to 4 percent of GDP -- that is, the 2 percent presently lost to crime and the 2 percent spent on controlling crime -- and still improve social well-being. This would amount to an average of about $\$ 54,000$ for each of the 5 or so million men incarcerated, put on probation or paroled. In fact, the favorable benefit-cost assessment of the Job Corps and of the highly publicized Perry Pre-School program depend in part on large estimated savings in criminal justice expenses due to

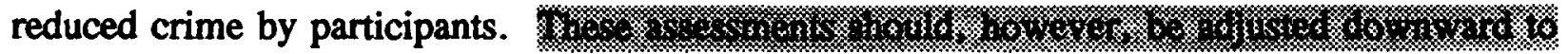

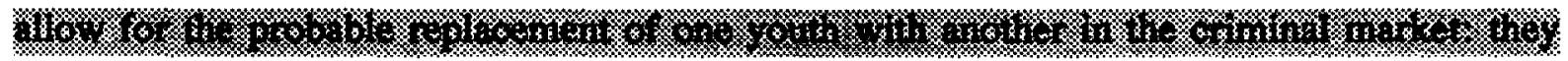

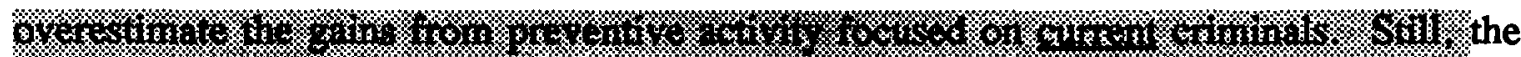
magnitude of the numbers does suggest the potential value of programs to assure that potential criminals have better access to legitimate employment opportunities.

Criminologists have argued in recent years about whether prison pays on the margin. In a much-disputed study published by the National Institute of Justice, Zedlewski (1987) reported the benefits of imprisonment exceeded the costs of imprisonment by 17 to 1 . But this estimate was based on each criminal otherwise committing 180 crimes; at more moderate estimates, the benefit-cost ratio of imprisonment exceeds one for the median number of 
crimes per criminal (12-15), but falls below one for those in the lower quartile or so of the distribution of crimes (Dilulio and Piehl, 1991). Consideration of the labor supply responses to criminal opportunities, which suggest sizeable replacement of incarcerated criminals by others, supports the lower estimates.

The debate on whether prison pays indicates that crime costs are high enough to justify incarceration of offenders at current U.S. levels, though perhaps not at much higher levels, and that altemative sentencing procedures would be cost effective for some current prisoners (Piehl and DiIulio, 1995). Braga and Clear (1995) offer a useful overview of these alternatives: house confinement, electronic surveillance, parole, and so on. The high costs of crime also suggest, however, that even a marginally effective and relatively costly jobs/crime prevention program for crime-prone groups would also pass a benefits-cost test. While I know of no "magic bullet" jobs or crime prevention program, it is a myth that all such programs invariably fail. Some have marginal positive effects. For instance, meta-analyses show that the average juvenile delinquency program has some deterrent effect, albeit modest (Lipsey, 1990). At least some anti-crime early intervention programs also succeed, again on a small scale (Mendel, 1995).

In any case, if I am correct that the collapse of the job market for less skilled men contributed to their increased involvement in crime, and if the supply of youth to crime is sufficiently elastic that the criminal justice system can at best cap the crime rate at rising costs, it is difficult to see any long term solution to crime that does not include some improvement in the labor market opportunities for less skilled youth. To make legitimate work more attractive to youths than crime requires, to be sure, increasing the likely penalty 
for crime, as has been the focus of recent U.S. policy, but it also could benefit from enhancing the rewards for legitimate work. A combined carrot and stick policy -- increased resources for police to prevent crime; incarceration of criminals during their most crimeintensive years (not at ages 40-60, as "three strikes and you're out" may due); and increased legitimate opportunities for the less skilled -- would seem to offer a way to deter at least some young men from committing crimes. The problematic part of any such policy, however, is the carrot part: finding legitimate opportunities for these young men. How to improve the job market for less skilled young American men, and reverse the huge decline in their earnings and employment opportunities is the problem of our times, with implications both for crime and many other other social ills. 
Exhibit 1: The Rising Propensity to Commit Crime

1977-1992 (1977 = 100)

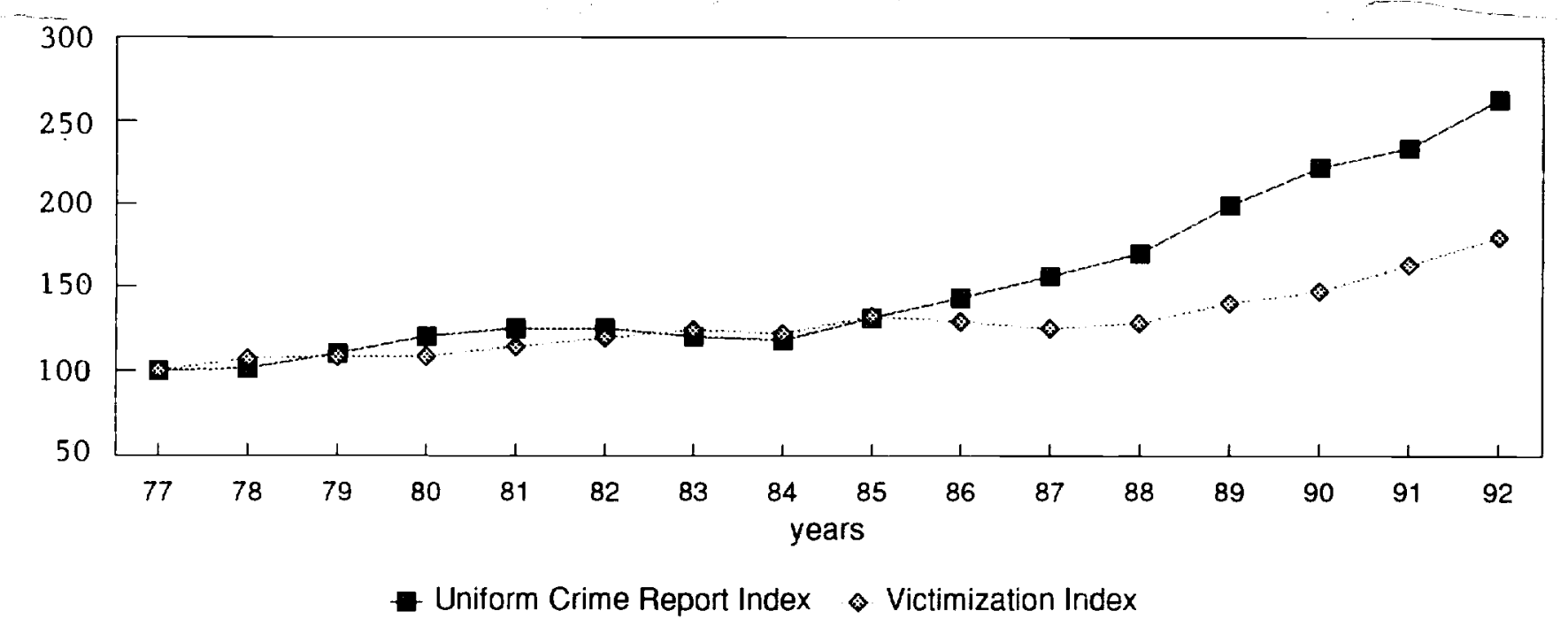

Source: Author's calculations as described in the text. 


\section{Exhibit 2: Criminal Earnings in 1980 and Future Incarceration}

$\begin{array}{ccc}\text { Proportion of Income from } & \text { Percentage Incarcerated } & \text { Sample Size } \\ \text { Crime, } 1980 & \text { Post-1980 }\end{array}$

None

Very Little

About $1 / 4$

About 1/2

About 3/4

Almost All
3.8

7.7

6.2

17.3

29.5

23.1
4385

984

128

98

44

52

Source: Tabulated from National Longitudinal Survey of Youth, question: "Sometimes people can make money from the types of activities you have just read ( a detailed list of crimes). Still thinking about the last year, how much of your total income or support during the last year came from illegal activities?

Numbers in parenthesis are sample sizes. 
Exhibit 3: Percentage Employed in Survey Week in 1980

by Criminal Behavior of Out of School Non-Military Youth

\begin{tabular}{lcccccc} 
& \multicolumn{2}{c}{ Response to Criminal Question } & \multicolumn{3}{c}{ Sample Sizes } \\
& Yes & No & Yes & No \\
\hline Admitted Committing Property Crime & 70.3 & 73.3 & 2369 & 1847 \\
Reported Positive Illegal Income & 66.0 & 73.2 & 951 & 3265 \\
Charged with Crime & 58.6 & 71.5 & 744 & 3279 \\
Jail in Following Year & 30.4 & 65.5 & 46 & 4223
\end{tabular}

Source: Tabulated from NLSY, with youths in school coded as missing. In these tabulations I have also excluded those in the military. Inclusion of youths in the military reduces the employment difference between those who reported crime and those who did not (strengthening the argument in the text) but does not noticeably affect the difference in employment rates for those in jail the following year.

(\# of observations) 


\section{Endnotes}

1. The number of men in prison is from U.S. Bureau of Justice Statistics, Bulletin Prisoners in 1993; the number of persons in jail is from U.S. Bureau of Justice Statistics, Bulletin Jail Inmates 1991 updated by assuming a rate of growth similar to that for those in prison.

2. For those on probation or parole, I extrapolated 1990 or 1991 figures (Freeman, 1995) to get $2,690,400$ probated after conviction for crime; 600,700 on parole, for a total of $3,291,100$ probated or paroled.

3. The percentages I report are obtained by dividing the number of prisoners in a group by the noninstitutionalized population plus the number of prisoners.

4. I have made these estimates by multiplying the number of dropouts in prison by the ratio of probatees or parolees to prisoners for the overall male population. These numbers may be biased upward, since judges may be less likely to sentence dropouts to probation than men with high school education or more.

5. These estimates are obtained by multiplying the percentage of male unemployed who are unemployed for over a year from OECD, Employment Outlook. July 1994, table Q with estimates of male unemployment from OECD Quarterly Labour Force Statistics, Number 4, 1994. The estimated male unemployment rate is from register data.

6. These are the two major sources of data on the volume of crime. Each year the FBI gathers the number of crimes reported by police, which is used to create the Uniform Crime Rate index. Each year the National Crime Survey asks households about victimizations for crimes. The two data sets differ in levels -- the UCR gives fewer crimes than the victimization survey, because people do not report all victimizations to the police, and in trend. For efforts to reconcile the two series, see Boggess and Bound (1993).

7. One difficulty is that most criminals are self-employed, and thus do not face a market wage but rather an earnings opportunity schedule in which hourly pay depends on the hours of work they choose. In the Boston Youth Survey,those who committed a single crime in the past year earned \$752, whereas those who reported committing crimes once a week or more earned $\$ 5376$, or $\$ 100$ or so per week -- considerably less per crime. A second reason in determining the income level of criminals is that self-reported criminal earnings may be inaccurately reported: Wilson and Abrahamse (1991) suggest that the incomes that inmates claim to have earned from various crimes are far higher than those crimes could plausibly yield.

8. Here, I take an average of the 1979 and 1980 deflators for the earnings in the Inner City Survey, since the survey covered both years. Using the 1979 deflator gives an estimated 3 percent drop in earnings, which is far short of the drop in legitimate earnings.

9. The Earned Income Tax Credit would raise the pay of those with family responsibilities modestly. But few young men in the crime-prone groups have families and are potential 
recipients of this support.

10. Since criminal earnings are poorly measured, it is not easy to document this claim. In the NLSY, I regressed the share of income from illegal sources on number of crimes reported, weeks worked in the year and three human capital measures: years of schooling, age, and AFQT score. The coefficients on all three human capital measures were negative and significant, implying that schooling, age, and AFQT lowered illegal income relative to legal income.

11. Because the NLSY has never repeated the crime module that was included in 1980 , evidence on future crime behavior is limited to whether or not the respondent was interviewed in jail or prison.

12. This leaves out some violent nonproperty crimes. Their inclusion increases the numbers committing crime without changing the results.

13. If the supply of crime is upward-sloping, the replacement will be less than one-for-one, dependent on the magnitude of the elasticities of supply and demand. Let $S=a W+S^{\prime}$ be the supply of youths to crime, where $W$ is the relative reward to crime. Assume that when more persons commit crimes, the rewards to crime fall according to a "demand" relation: $\mathrm{F}=-\mathrm{bW}$ $+D^{\prime}$ measure criminal opportunities. Market equilibrium is $=\left(a D^{\prime}+b^{\prime}\right) /(a+b)$. When incarceration reduces the supply of criminals by $\mathrm{dS}^{\prime}$, the change in the number of criminals is $b d S^{\prime} /(a+b)$ rather than $d S^{\prime}$. The replacement effect is $a /(a+b)$.

14. It's worth noting that the resultant estimates of the reduction in reported crimes or victimizations due to incapacitation are in the ballpark of the lower estimated range crimes per criminal reviewed earlier; that is, the median number of 5-15 crimes per criminal, not the 60180 crimes per criminal reported in prisoner surveys.

15. I use the word "legitimate" to justify including property losses as part of the cost of crime. From one perspective (mine), my picking your pocket is not a social loss; it is simply a transfer of income. Some calculations of the cost of crime exclude the property loss. Others include it. For certain purposes, we may want to distinguish between "Robin Hood" crimes that redistribute money from one person to another (picking pockets, for instance) and crimes that are purely destructive (arson, assault). The question in part hinges on the definition of society.

16. Levitt (1995) reports $\$ 45,000$ as the estimated cost per criminal and estimates that criminals commit 15 crimes per year, for the $\$ 3,000$ per crime estimate that I use.

17. Annual current operating expenditures for prisoners are on the order of $\$ 15,000$ (Piehl and Dilulio, 1995). Estimates of the amortized value of prisons are on the order of $\$ 4,000$ to $\$ 5,000$ (Cavenaugh and Kleiman, 19XX table 2). 


\section{References}

Blackburn, Kim, David Bloom, and Richard Freeman, "The Declining Economic Position of Less Skilled American Men", in Gary Burtless (ed), A Future of Lousy Jobs? The Changing Structure of U.S. Wages. Washington, DC: Brookings Institution, 1990.

Boggess, Scott and John Bound, "Did Criminal Activity Increase During the 1980s? Comparisons across Data Sources" National Bureau of Economic Research Working Paper 4431, Cambridge Mass, August, 1993.

Boyum, David and Mark A.R. Kleiman, "Alcohol and Other Drugs", in Crime (ed J.Q. Wilson and Joan Petersilia) 171-192. San Francisco: Institute for Contemporary Studies, 1995.

Cavanagh, David P. and Mark A.R. Kleiman, "A Cost Benefit Analysis of Prison Cell Construction and Alternative Sanctions." (Cambridge, MA: BOTEC Analysis Corp.) June, 1990. (Prepared for the National Institute of Justice.)

Chiricos, Theodore, "Rates of Crime and Unemployment: an Analysis of Aggregate Research Evidence." Social Problems 34, no 2 (April, 1987): 187-211.

Clear, Todd and Anthony Braga, "Community Corrections", in Crime (ed J.Q. Wilson and Joan Petersilia) 171-192. San Francisco: Institute for Contemporary Studies, 1995.

Cohen, Mark A. "Pain, Suffering, and Jury Awards: A study of the cost of crime to victims" Law and Society Review volume 22, number 3 (1988), pp 537-555

Dilulio, John and Piehl, Anne "Does Prison Pay?" The Brookings Review (Fall, 1991) pp 29-35.

Elliot, Delbert "Longitudinal Research in Criminology: Promise and Practice" in G. W. Westekamp and H.J. Kerner (eds) Cross National Longitudinal Research on Human Development and Criminal Behavior Kluwer Academic Publishers, Netherlands, 1994.

Fagan, Jeff "Drug Selling and Licit Income in Distressed Neighborhoods: The Economic Lives of Street-Level Drug Users and Dealers" in Drugs, Crime and Social Isolation (ed Adele Harrell and George Peterson). Washington, Urban Institute Press, 1991.

2Freeman, R., "Crime and the Labor Market" in Crime and Public Policy (ed J.Q. Wilson) 89-106. San Francisco: Institute for Contemporary Studies, 1983.

Freeman, R. "The Relation of Criminal Activity to Black Youth Employment" The Review 
of Black Political Economy, Summer-Fall 1987, 99-107.

Freeman, R., "Crime and the Employment of Disadvantaged Youth" in Urban Labor Markets and Job Opportunity (ed George Peterson and Wayne Vroman). Washington D.C. Urban Institute, 1992.

Freeman, R., "The Labor Market" in Crime (ed J.Q. Wilson and Joan Petersilia) 171-192. San Francisco: Institute for Contemporary Studies, 1995.

Grogger, J., "Criminal Opportunities, Youth Crime, and Young Men's Labor Supply", Department of Economics, University of California, Santa Barbara, February, 1994.

Hageborn J. "Homeboys, Dope Fiends, Legits, and New Jacks" Criminology vol 32, number 2, 1994, 197-219.

Hindelang, M.J., Hirschi,T. and Weis, J., Measuring Delinquency Beverley Hills Calif, Sage, 1981.

Juhn, Chinui, Kevin Murphy, and Robert Topel, "Why Has the Natural Rate of Unemployment Increased Over Time?" Brookings Papers on Economic Activity (1991, vol 2, 75-142).

Klaus, Patsy " The Costs of Crime to Victims" Crime Data Brief, U.S. Department of Justice, February 1994.

Land, K.C., Patricia McCall, and Lawrence Cohen, "Structural Covariates of Homicide Rates: Are there any invariances across time and social space?" American Joumal of Sociology 95, no 4 January, 1990, 922-63.

Langan, Patrick, "America's Soaring Prison Population" Science 251 (March 29, 1991): 1568-73.

Lattimore, P., Witte, A., Baker, J., "Experimental Assessment of the Effect of Vocational Training of Youthful Property Offenders" NBER working paper 2952, April 1989.

Lee, David Sang-Yoon, "An Empirical Investigation of the Economic Incentives for Criminal Behavior", B.A. Thesis in Economics, Harvard University, March, 1993.

Levitt, Steven, "The Effect of Prison Population Size on Crime Rates: Evidence from Prison Overcrowding Litigation", Harvard University, February 1995.

Lipsey, Mark W., "Juvenile Delinquency Treatment: A Meta-Analytic Inquiry into the Variability of Effects", Claremont Graduate School, February 1990. 
Marvell, Thomas and Carlisle Moody, "Prison Population Growth and Crime Reduction" Journal of Quantitative Criminology, vol 10, no2, 1994, pp 109-140.

Mendel, Richard A., "Prevention or Pork? A Hard-Headed Look at Youth-Oriented AntiCrime Programs" Washington D.C., American Youth Policy Forum, 1995.

Miller, Ted, Mark Cohen, and Shelli Rossman, "Victim Costs of Violent Crime and Resulting Injuries" Data Watch 1993.

Mishel, Lawrence and Aaron Bernstein, The State of Working America 1994-95 (Economic Policy Institute, M.E. Sharpe, Armonk New York, 1994)

Needels, Karen, "Go Directly to Jail and Do Not Collect? A Long-term Study of Recidivism and Employment Patterns Among Prison Releases" Department of Economics, Princeton University, November, 1993.

Piehl, Anne and John Dilulio, "Does Prison Pay? revisited" The Brookings Review (Winter 1995) pp 21-25.

Phillips. L. and Votey, H., "Demographics and Trends in Crime: A Failed Hypothesis (University of California, Santa Barbara, May 1990).

Piehl, A. and J. DiIulio, "Does Prison Pay?" Revisited" The Brookings Review (winter, 1995), 21-25.

Reuter, P. MacCoun, R. and Murphy, P., Money from Crime (Rand 1990).

Spelman, W.Criminal Incapacitation Plenum Press, New York, 1994.

Topel, Robert, "What Have We Learned from Empirical Studies of Unemployment and Turnover?" American Economic Association. Papers and Proceedings, May 1993, pp 110-115.

U.S Bureau of the Census, The Black Population in the United States: March 1994 and 1993 Current Population Reports, Series P20-480. (U.S. GPO, Washington D. C. , 1995).

U.K. Central Statistical Office, Social Trends 1995 (London, 1995).

U.S. Department of Justice, Bureau of Justice Statistics Crime in the United States, various editions Sourcebook of Criminal Justice Statistics, various editions Recividism of Prisoners Released in 1983 (1994) Survey of State Prison Inmates. 1991 (1993) 
U.S. Bureau of the Census Statistical Abstract, various years.

Viscusi, K. "Market Incentives for Criminal Behavior", in Freeman, R. and Holzer, H. (ed) The Black Youth Employment Crisis. Chicago: University of Chicago Press, 1986.

Wilson J. and Allan Abrahamse, "Does Crime Pay?" Justice Quarterly 9, no 3 (September, 1992. pp 359-77.

Wilson, James and Joan Petersilia (ed), Crime (Institute for Contemporary Studies, San Francisco, California, 1995.

Zedlewski, Edwin "Making Confinement Decisions" U.S. Department of Justice, Washington D.C. 1987. 